\title{
The Correlation between Morphological Awareness and Vocabulary Mastery of the Fifth Semester Students of English Department Students of FKIP Universitas Riau
}

\author{
Nyayu Muharomah Arviyolla', SyofiaDelfi $i^{2}$, Dahnilsyah ${ }^{3}$ \\ Universitas Riau ${ }^{1,2,3}$ \\ arviiyollaa7@gmail.com ${ }^{1}$; syofia.delfi@lecturer.unri.ac.id ${ }^{2}$; dahnilsyah@lecturer.unri.ac.id ${ }^{3}$
}

\begin{abstract}
This research aimed to discover the Correlation between morphological awareness and vocabulary Mastery of the $5^{\text {th }}$ semester Students of English Department of FKIP Universitas Riau. The research design was correlation design for the student's morphological awareness and vocabulary mastery. There were 39 students of the 5th semester of English Department of FKIP Universitas Riau selected by using cluster random sampling. The research instrument of this study were morphological awareness test and vocabulary level test. These instruments were used to answer the research questions of this study. The result of data analysis showed that 59.84 of frequency distribution mean score of morphological awareness in which it was moderate level. Meanwhile, 71.61 of frequency distribution mean score of vocabulary mastery were high vocabulary level. Additionally, the correlation coefficient was 0.601 , which was on a scale from 0.00 - 1.00. The findings of this study indicating a positive and strong correlation between two variables indicating the correlation between students' morphological awareness and their vocabulary mastery was classified as strong correlation. Based on the findings of this study, it is suggested that the students need to be facilitated to the context of learning vocabulary based on understanding word forms. It is also recommended to reduplicate this study for other English Education students in Riau Province by having larger number of sample.
\end{abstract}

\begin{abstract}
ABSTRAK
Penelitian ini bertujuan untuk menemukan. Korelasi. antara kesadaran morfologi dan penguasaan kosakata mahasiswa semester 5 FKIP bahasa Inggris, Universitas Riau. Desain penelitian ini adalah desain korelasional untuk kesadaran morfologi dan penguasaan kosakata mahasiswa. Terdapat 39 mahasiswa semester 5 Jurusan Bahasa Inggris FKIP Universitas Riau yang dipilih dengan menggunakan cluster random sampling. Instrumen penelitian dalam penelitian ini adalah tes kesadaran morfologi dan tes tingkat kosakata. Instrumen-instrumen tersebut digunakan untuk menjawab pertanyaan penelitian dalam penelitian ini. Hasil analisis data menunjukkan 59,84 distribusi frekuensi rata-rata skor kesadaran morfologi berada pada taraf sedang. Sedangkan 71,61 distribusi frekuensi rata-rata skor penguasaan kosakata berada pada tingkat kosakata tinggi. Selain itu, koefisien korelasi adalah 0,601, yang berada pada skala 0,00
\end{abstract}

\section{KEYWORDS}

morphological awareness; vocabulary mastery

\section{KATA KUNCI}

kesadaran morfologi; penguasaan kosakata 
Nyayu Muharomah Arviyolla ${ }^{1}$,SyofiaDelfi ${ }^{2}$,Dahnilsyah ${ }^{3}$,

J-SHMIC: Journal of English for Academic

Vol 9, No 1, February 2022

- 1,00. Temuan penelitian ini menunjukkan korelasi positif dan kuat antara dua variabel yang menunjukkan korelasi antara kesadaran morfologi siswa dan penguasaan kosa kata mereka tergolong korelasi kuat. Berdasarkan temuan penelitian ini, disarankan agar siswa perlu difasilitasi untuk konteks pembelajaran kosakata berdasarkan pemahaman bentuk kata. Direkomendasikan juga untuk mereduplikasi penelitian ini untuk mahasiswa Pendidikan Bahasa Inggris lainnya di Provinsi Riau dengan jumlah sampel yang lebih banyak.

\section{INTRODUCTION}

Language learners in learning a language recognize a sentence in which it consists of a group of words that are put together to mean something. They should know how a sentence is arranged systematically in order to have a meaning. Besides, they have to recognize words systematically in order they can use the words in appropriate usage. It means that the learners need to recognize word formation before arranging the words to be a sentence. By understanding the word formation, they recognize classes of words in which they differentiate the use of words. It is expected that the students should know elements relating to word formation: prefixes, suffixes, conversion and compounds.

The language learners majoring in English education learn about word formation in Morphology course. To the context of this study, English Department students of Universitas Riau learn Morphology at fifth semester and it is assumed that they have mastered word formation. Before conducting the research, two activities were done as initial studies. The first one was by studying thoroughly the previous researches conducted at the same context and by conducting informal interview. The writer noticed that one of the studies about morphological awareness focused on spoken form of morpheme through allomorph, then the written form of morpheme through syntactic, and phonological and orthographic changes as a study conducted by (Khairunnisa et al., 2019). Whereas, (Khairumi et al., 2020) only focused on the syntactic aspect. However, this current study focuses on morphological awareness that have two aspects such as morpheme identification and morphological structure test in order to influences the vocabulary mastery.

After studying the previous researches, informal interview done. The result showed that $20 \%$ of the 5th semester students of English Department of FKIP Universitas Riau pay less attention on the importance of morphological awareness and learning vocabulary. It showed that $20 \%$ of them were confused about recognizing the morpheme and the way of add morpheme that may affect the grammatical and the meaning of a word. It means that they have some weaknesses in understanding derivational and inflectional morpheme roles that are used in a given context. Meanwhile, they are supposed to recognize morphemes after finishing Morphology subject. In learning vocabulary, the students just tried to investigate the meaning of a word but did not try to understand the words grammatically. As a result, they tend to 
consult dictionary and spent time to understand reading materials for their assignment or texts for exam.

English First (EF) arranged the English Proficiency Index (EPI) data for 2020, which shows Indonesia was ranked 74th out of 100 countries worldwide and 15th out of 24 Asian countries (EF Education First, 2020). The score of Indonesian was 453 on average and categorized as low proficiency level. (Ali Saukah, 2016) points out that students majoring in Indonesian English also get low proficiency. (Renandya et al., 2018) found that a professional teacher of a foreign language should possess both adequate content knowledge and adequate pedagogical content knowledge for effective instruction in the target language. Despite the fact that teaching methods are effective no automatically guarantee by language proficiency that research has shown that a high level of proficiency of teachers tend to provide their students with a more adequate language support by using the language in class tasks. This demonstrates that as studentteachers, the fifth semester students need to know how to construct a word that affects a word's meaning and grammatical structure.

Morphological awareness could be as an useful approach for EFL university students in learning language, especially English. This recommendation is in accordance with this strategy was proposed by (Morin, 2003: 87) who used morphological knowledge to infer words' meanings. Studies have shown that there was correlation between morphological awareness and vocabulary mastery level (Adam, 2018) and (Ibrahim Rabadi, 2019). However, (Novawan et al., 2020) found that there was no significant correlation between morphological awareness and vocabulary knowledge. One of the possible reasons for different finding may refer to the level of the students. The participants of Adam's study (2018) were senior high school students. Meanwhile, the participants in (Ibrahim Rabadi, 2019) as well as (Novawan et al., 2020) were university level. Even though (Ibrahim Rabadi, 2019) and (Novawan et al., 2020) had the same level of the participants but the findings were contrast.

\section{Morphological Awareness}

According to (Hafizh Ana Nafiah, 2017), Morphological awareness is students' comprehending of morphological structures in which they are able to use knowledge during morphological processing in visual word acknowledgment. Morphological awareness, in accordance with (McBride-Chang et al., 2005) is the Morphological awareness (MA) is a recognition or an awareness where approach to the meaning of a word and the structure of morphemes in connection to words. This explanation relates to both knowledge of derivations and inflections. Derivational morphology includes prefixes (e.g. dis in disagree), suffixes (e.g. -ful in hopeful), and compounding (e.g. child + hood $=$ childhood $)$. Subsequently, inflectional morphology concentrate on grammatical changes in sentences, especially in words(e.g. $-s$ in birds, -ed in stayed, ing in looking). students' awareness of morphology plays on both derivational morphology and inflectional morphology.

As defined by Morphological awareness can be categorized as the ability to apply knowledge of the rules of word formation and also of the pairing among sound and meaning. The focus is on the morphemes of words. The morphological awareness, 
Nyayu Muharomah Arviyolla ${ }^{1}$,SyofiaDelfi ${ }^{2}$,Dahnilsyah ${ }^{3}$,

J-SHMIC: Journal of English for Academic

Vol 9, No 1, February 2022

therefore, points to the ability to perceive and understand the complex words with its meaning, as well as language properties such as their base and suffixes. A lot of research on morphological awareness between young learners focuses on the ability to recognize sounds.

Students reflect on and modify word construction norms to infer the new words along with their meaning without the assistance of a communication context, according to the construct of morphological awareness. This study found that morphological awareness leads to the student's usage of morphemes, which allows students to recover the meaning of following new complex words by morpheme identification or breakdown, as well as recombine morphemes to create new meanings through morphological structures

\section{Aspects of Morphological Awareness}

There are two Aspects of morphological awareness (MA): syntactic and synthesis. Morpheme identification awareness the syntactic aspect, and morphological structure Awareness is the synthesis aspect.

\section{a. Morpheme Identification Awareness}

Morpheme identification awareness is one component of morphological awareness. The ability to detect distinct meanings across homophones, (McBride-Chang et al., 2005) reveal morpheme identification awareness. She exhibited this capability by demonstrating what happens when a language learner recognizes that the bloom in a plant With petals is the flowerpot rather than a sack of white powder (flour). The next example is when a language students tell the difference between the sound of the word dead in a spoken language and the sound of the word debt. The focus in this case is on how the learner can use homophones for vocabulary acquisition by focusing on his acquired words as homophones, as well as how the student can distinguish homophones.

A morpheme identification awareness is presented in this study. For example, morphemes are defined in this study as the lowest meaningful unit of language, which is a word. Morphemes were formerly defined as sounds, however the work provided here identifies them as the unit of meaning of each word. Morpheme Identification or the syntactic aspect can be defined as the ability to discern between distinct meaning by looking at the components of a word's composition.

\section{b. Morphological Structure Awareness}

Morphological structural awareness is the next aspect of morphological awareness (MA). Morphological structural awareness, according to (Berko in McBridge, 2005), is the ability to develop new meanings by combining familiar morphemes. That researcher looked into how children's grammatical understanding demonstrates this ability. A youngster with morphological structural awareness understands that the renowned concept of more than one wug is described by the word wugs, which consists of two morphemes. This example determines morphological inflectional understanding. 
Similarly, (McBride-Chang et al., 2005) reveal morphological structural awareness as the learners' ability to extract new meaning from their linguistic expertise. It highlights language parts and new meaning, similar to the prior concept. It connects receptive skills with productive skills. Learners who understand the notion of present participles will realize that present participles are formed by combining present verbs with the suffix ing. As a result, they can create new meanings for words that are recognized as present verbs by adding the suffix -ing to turn them into present participles. Furthermore, because present participles may be transformed into adjectives, students can create new words as adjective from existing present participles, such as confusing, amazing, and boring. To generate new meaning and confirm whether the words are in English, morphological structure awareness necessitates comprehensive awareness. For example, by adding the suffix - esto to the word cactus, a new word can be created. Cactuses is the word. The new word, however, is erroneous since cactus cannot be replaced with es instead of cacti. For example, in order to appropriately construct new words, learners should have a good understanding of morphemes.

To summarize, morphological structure is relevant to its ability to create new word form various morphemes that have been studied by students before. Students are required to understand the meaning and application of affixes (inflections and derivations). Learners must be able to conduct productive verbal skills based on the information they gain from receptive activities like reading and listening.

\section{Vocabulary Mastery}

The level of vocabulary mastery is defined as the position or status in a scale of values (Hornby, 2015). In line with this definition, (Nation, 2001) points out that Vocabulary Levels Test is a test which allows the teachers or learners to decide the kind of vocabulary to work on. It shows that not only the teachers are expected to know their students' vocabulary mastery level but also the students should know their vocabulary mastery level.

The vocabulary mastery levels are clarified into five (Webb et al., 2017). The classifications refer to the frequency: 2000, 3000, 5000, and 10000 academic vocabulary word level. (Anisa, 2016) classifies them into four various categories. They are high frequency words, technical words, academic words, and low frequency words. The categories are based its frequency and its range. High frequency words are classified as words occurring very frequently. The words are used frequently in formal and informal situation. They are also used in written and spoken.

Academic words are classified as the words occurring in academic texts in certainty of the frequency. Technical words are words occurred in academic context. Low frequency words are classifies as the rare words in most texts. These levels relate to one's background knowledge and reading materials that they read for courses and interest. (Webb et al., 2017) develops the classifications into five levels; 1000, 2000, 3000, 4000, and 5000 word level. In short, the description of vocabulary mastery level is an amount of word numbers in understanding vocabulary knowledge or skill. It allows students to realize their position which is started from very low to high level. Considering the ability 
Nyayu Muharomah Arviyolla ${ }^{1}$,SyofiaDelfi ${ }^{2}$,Dahnilsyah ${ }^{3}$,

J-SHMIC: Journal of English for Academic

Vol 9, No 1, February 2022

of recognizing the words would assist the students to acquire the study of vocabulary words. Students majoring in English need to consider their vocabulary level. (Emelia Agustianti et al., 2021) found that the students' mastery on vocabulary level is also as the effect of their vocabulary learning strategy.

As discussed earlier, contextually and conceptually morphological awareness and vocabulary mastery are supposed to relate each other. The students' understanding on linguistics aspect is really expected because it may affect on the other language skills as discussed by (Delfi \& Yamat, 2017). They point out that one of the causes of the different reading level of EFL in reading is in terms of their linguistic knowledge. Understanding the relation of morphological awareness and vocabulary mastery is beneficial for language learners. Therefore, this current study is conducted to investigate the correlation between morphological awareness and vocabulary mastery of the fifth semester students of English Department of FKIP Universitas Riau.

\section{METHOD}

This research used descriptive quantitative method. Specifically, this research design was correlational study. Correlation is the types in quantitative approach. In correlational research, investigator used the correlational statistical test to describe and measure the degree of association (or relationship) between two or more variables or sets scores (Creswell, 2012). It was focused on the research to find out the relationship of two or more variables. Moreover, it concentrated in numerical data. Thus, in analyzing the data of the research, the Microsoft excel and SPSS 25 program was used to calculate the statistical data.

The participants of this research were 39 students of the fifth semester students of English Department of FKIP Universitas Riau. Random sampling was used in which it can be described as the process of selecting a sample randomly with similar characteristics (Gay et al., 2012). To the context of this study, the cluster random Sampling was used because the samples of this research had the same level of education background, the5th semester students of English Department of FKIP Universitas Riau who had finished Morphology class. To choose the samples, lottery was used in this research. Every chairman chose the decision roulette. The sample of this research is determined by the decision roulette. As the result, 5B class was selected as the sample. There were 39 students in the class, and all of them is taken as the sample of this research.

To get the scores of the data of morphological awareness, the test was adapted from (McBride-Chang et al., 2005) by considering some of aspects of morphological words such as inflection words, derivation words, compound words and stem. There were 40 items that valid and reliable. The data of the test were analyzed by comparing the $r$ value and the $t$ table. To classify the students' morphological awareness test, there were (morphological structure test and morpheme identification test). For morphological awareness test, the students were tested in this research of their morphological awareness by online test. The vocabulary mastery level test was used to determine the result of vocabulary level for five word levels: 1000, 2000, 3000, 4000, and 5000 (Webb et al., 
2017). The aspect that consists of the vocabulary test were divided into three main feature of noun, verb, and adjective. The instrument was adopted and it was already useable and consistent. Therefore, there were 50 items that applied to measure the mastery level of the students.

To make the classification of the variable scores, as for the descriptive statistics of the test items such as mean and standard deviation were calculated with the support of Microsoft Excel formulas. In determining the validity of the test items, the difficulty level of the test items was initially considered. The test item is classified as a rejected item as a too difficult question if the difficulty index is between $0.00-0.30$ and a too easy question if the level is between 0.71-1.00. The ideal level of difficulty stands between 0.31 to 0.70 that means the test item is accepted. A range of correlation coefficients, ranging from 0.00 to -1.00 , are displayed as the end result of data analysis. The Pearson $r$, a measure of correlation that is acceptable when both variables to be correlated are expressed as continuous (i.e., ratio or interval) data, is used to assess correlation studies using the product moment correlation coefficient technique (Gay et al., 2012). There were a few stages involved in using the SPSS 25 application to analyze the data.

\section{FINDINGS AND DISCUSSION}

The finding of this research was based on the finding of the analysis from both variables; the vocabulary level $(\mathrm{X})$ and the vocabulary learning strategy $(\mathrm{Y})$. . In order to make distribution Based on the total score of MA (Morphological Awareness) test of students, frequency distribution would be given as frequency distribution score and mean. The descriptive statistics of the real data test was calculated, as follows:

Table 1: Descriptive Statistics of the Real Data Test

\begin{tabular}{|r|c|c|c|c|c|c|}
\hline & N & Max. & Min. & Range & K & P \\
\hline MAT & 39 & 90 & 33 & 57 & 7 & 9 \\
\hline
\end{tabular}

According to the Table 1, the maximum score of MA test was 90. While the minimum score of MA score was 33. In order to know the mean of variable X(MA), it counted as follow:

Table 2: Frequency Distribution Mean Score of MA test of students in English Department of FKIP Universitas Riau

\begin{tabular}{|c|c|c|c|c|c|}
\hline INTERVAL & $\mathrm{F}$ & $\mathrm{F} \%$ & $\mathrm{X}$ & FX & MEAN \\
\hline $33-41$ & 6 & $15 \%$ & 37 & 222 & \multirow{8}{*}{$\begin{aligned} M & =\frac{F x}{N} \\
& =\frac{2334}{39} \\
& =59.84\end{aligned}$} \\
\hline $42-50$ & 8 & $21 \%$ & 46 & 368 & \\
\hline $51-59$ & 5 & $13 \%$ & 55 & 275 & \\
\hline $60-68$ & 6 & $15 \%$ & 64 & 384 & \\
\hline $69-77$ & 8 & $21 \%$ & 73 & 584 & \\
\hline $78-86$ & 5 & $13 \%$ & 82 & 410 & \\
\hline $87-95$ & 1 & $3 \%$ & 91 & 91 & \\
\hline TOTAL & 39 & 100 & & 2334 & \\
\hline
\end{tabular}


Nyayu Muharomah Arviyolla ${ }^{1}$, SyofiaDelfi ${ }^{2}$, Dahnilsyah $^{3}$,

J-SHMIC: Journal of English for Academic

Vol 9, No 1, February 2022

According to the findings of Table 2, the mean of participants in 5B class was 59.84. It shows that the level of the students' morphological awareness is moderate. The level indicating the quality of the finding is as the following table.

Table 3: Quality of Variable of the Score Students' MA test

\begin{tabular}{|r|l|}
\hline Score & \multicolumn{1}{|c|}{ Level } \\
\hline $81-100$ & Very High \\
\hline $61-80$ & High \\
\hline $41-60$ & Moderate \\
\hline $21-40$ & Low \\
\hline $00-20$ & Very Low \\
\hline
\end{tabular}

According to Table 3, the writer concluded that mean score of students in MA (Morphological Awareness)test was categorized in the interval 41 - 60. It meant that the morphological awareness of students was "Moderate". In order to make distribution Based on the total score of VLT (Vocabulary Level Test) of students, frequency distribution would be given as frequency distribution score and mean. In order to make distribution, The descriptive statistics of the real data test was calculated, as follows:

Table 4: Descriptive Statistics of the VLT Test

\begin{tabular}{|c|c|c|c|c|c|c|}
\hline & N & Max. & Min. & Range & K & P \\
\hline MAT & 39 & 92 & 36 & 56 & 7 & 9 \\
\hline
\end{tabular}

Table 4 shows that the maximum score of VLT test was 92 . While, the minimum score of VLT score was 36 . In order to know the mean of variable X (MA), it counted as follow:

Table 5: Frequency Distribution Mean Score of MA test of students in English Department of FKIP Universitas Riau

\begin{tabular}{|c|c|c|c|c|c|}
\hline INTERVAL & $\mathrm{F}$ & $\mathrm{F} \%$ & $\mathrm{X}$ & FX & MEAN \\
\hline $36-44$ & 7 & $18 \%$ & 40 & 280 & \multirow{8}{*}{$\begin{aligned} M=\frac{F x}{N} & \\
= & \frac{2793}{39} \\
= & 71.61\end{aligned}$} \\
\hline $45-53$ & 1 & $3 \%$ & 49 & 49 & \\
\hline $54-62$ & 4 & $10 \%$ & 58 & 232 & \\
\hline $63-71$ & 5 & $13 \%$ & 67 & 335 & \\
\hline $72-80$ & 7 & $18 \%$ & 76 & 532 & \\
\hline $81-89$ & 5 & $13 \%$ & 85 & 425 & \\
\hline $90-98$ & 10 & $26 \%$ & 94 & 940 & \\
\hline TOTAL & 39 & $100 \%$ & & 2793 & \\
\hline
\end{tabular}


According to the result of Table 5, the mean of participants in 5B class was 71.61. To know the quality of the result, the table below was given:

Table 6: Quality of Variable of the Score Students' MA test

\begin{tabular}{|l|l|}
\hline Score & Level \\
\hline $81-100$ & Very High \\
\hline $61-80$ & High \\
\hline $41-60$ & Moderate \\
\hline $21-40$ & Low \\
\hline $00-20$ & Very Low \\
\hline
\end{tabular}

According to the table.6, the writer concluded that mean score of students in VLT (Vocabulary Level Test) test was categorized in the interval 61 - 80. It meant that the Vocabulary Level Test of students was "High".

In order to get the answer of the last research question whether there is relationship between variable X (morphological awareness) and variable Y (vocabulary mastery) of the $5^{\text {th }}$ semester student of English Department, the writer used statistical hypothesis using Pearson Product Moment as follow: The writer used Pearson Product Moment using SPSS 25.0 to make the result more valid, The result obtained from this computation was showed in the following table:

Table 7: SPSS Analysis of Pearson Correlations between Morphological Awareness Test And Vocabulary Level Test

\begin{tabular}{|c|c|c|c|}
\hline \multicolumn{5}{|c|}{ Correlations } \\
\hline \multirow{4}{*}{ MAT } & $\begin{array}{c}\text { MA } \\
\text { T }\end{array}$ & VLT \\
\hline \multirow{4}{*}{ VLT } & $\begin{array}{c}\text { Pearson } \\
\text { Correlation }\end{array}$ & 1 & $.601^{* *}$ \\
\cline { 2 - 5 } & $\begin{array}{c}\text { Sig. }(2- \\
\text { tailed) }\end{array}$ & & 0 \\
\cline { 2 - 5 } & $\mathrm{N}$ & 39 & 39 \\
\hline \multirow{2}{*}{$* *$ Correlationis significant at the 0.01level(2-tailed). } & $\begin{array}{c}\text { Pearson } \\
\text { Correlation }\end{array}$ & $.601^{*}$ & 1 \\
\cline { 2 - 5 } & $\begin{array}{c}\text { Sig. }(2- \\
\text { tailed) }\end{array}$ & 0 & 39 \\
\cline { 2 - 5 } & $\mathrm{N}$ & 39 & \\
\hline
\end{tabular}

Table.7 showed the SPSS analysis of Pearson Correlation coefficient between the scores of morphological awareness and vocabulary level tests to 39 students. The Pearson Analysis 
Nyayu Muharomah Arviyolla ${ }^{1}$,SyofiaDelfi ${ }^{2}$,Dahnilsyah ${ }^{3}$,

J-SHMIC: Journal of English for Academic

Vol 9, No 1, February 2022

produced a positive average correlation of 0,601 , which meant students' morphological awareness was found to be correlated with their vocabulary mastery. This Correlation Analysis was calculated at $0,05(5 \%)$-level but the result showed that this calculated was also significant at $0,01-$ level ( $1 \%)$ margin of error.

Table 8: Interpretation of Number Correlationr ${ }_{x y}$ product Moment

\begin{tabular}{|l|l|}
\hline $\begin{array}{l}\text { Correlational } \\
\text { Value (r) }\end{array}$ & $\begin{array}{l}\text { Interpretation } \\
\text { of Correlation }\end{array}$ \\
\hline $0,00-0,199$ & Very Low \\
$0,20-0,399$ & Low \\
$0,40-0,599$ & Fair \\
$0,60-0,799$ & Strong \\
$0,80-1,000$ & Very Strong \\
\hline
\end{tabular}

(Adopted from Sugiyono, 2017)

Table.8. showed the SPSS analysis of Pearson Correlation coefficient between the scores of morphological awareness and vocabulary mastery tests to 39 students. The Pearson Analysis produced a positive average correlation of 0,601 Thus, students' morphological awareness and vocabulary mastery were found to correlate and categorized in "Strong Correlation".

The students' overall morphological awareness was moderate, according to the findings (59.84). This suggests that the participants have a good comprehension of how words are morphologically organized. The morphological awareness of language learners can be used to predict vocabulary knowledge (Khodadoust et al., 2013; Adam., 2018; McBride -Chang et al., 2005). Furthermore, pupils fared worse in the morphological structure (Score total $=526$ ) than they did in the Morpheme identification (Score total=403). Their inadequate Morpheme Identification result reveals their inability to recognize morphological words.

In accordance with the results of the Morphological Awareness Test, it will be important for EFL classes to explicitly teach morphological structure and morpheme identification. The current students' vocabulary performance on the Level Test (VLT) indicated that students performed better at the first 1000 levels than the 5000 levels. The outcomes have revealed that the students' overall Vocabulary Level Test (VLT) was high (71.61). In this present study, from the 1000 levels until 5000 levels from the total score such as 1000 levels (1044), 2000 levels (919), 3000 levels (806), 4000 levels (758), 5000 levels (643). Meanwhile, at level 5000 there were still many who lacked of knowledge of unfamiliar words It can be concluded that the easiest words and familiar words is in the first 1000 levels. These findings support the reveals of (Webb et al., 2017), students who are beginners will have a difficult time understanding the information contained in words and context to decipher the unknown derivation due to a lack of receptive knowledge of the part of the word and a limited breadth of knowledge. Additionally, creating a test for beginning learners that focuses on testing their understanding of the most commonly occurring lemmas identified in (Ngoc Yen Dang \& Webb, 2016) Essential Word List could be beneficial. 
Based on the research finding, to test the hypothesis, it was done by compare $r_{\text {value }}$ with $r_{\text {table }}$ of Pearson Product Moment with $\mathrm{n}=(39)$. Based on the hypothesis analysis above, the point of $r_{\text {value }}$ is 0,601 and $r_{\text {table }}$ with $\mathrm{n}=39$, and the $r_{\text {table }}$ of $\mathrm{n}=39$ is 0,316 . As the result of the criteria above, the writer got the fact that $r_{\text {value }}$ was higher than $r_{\text {table }}(0,601>0,316)$. As a result, $\mathrm{H} 0$ was denied and $\mathrm{H} 1$ was approved. As a result, the conclusion was that there was a substantial association between Morphological Awareness (variable X) and Vocabulary Mastery (variable Y) of fifth Semester students KIP Universitas Riau . It shows that there was a correlation between Morphological Awareness as an independent variable and Vocabulary Mastery as a dependent variable of fifth Semester students of FKIP Universitas Riau .

In addition, the correlation between morphological awareness and vocabularymasteryofstudentsintable4.11wherePearsonCorrelationusingSPSS

25 wascalculated showed that the SPSS analysis of Pearson Correlation coefficient among the scores of morphological awareness and vocabulary mastery tests to 39 students. The Pearson Analysis produced a positive average correlation of 0,601 which meant students' morphological awareness was discovered to be correlated with their vocabulary mastery and categorized in "Strong Correlation".

Ibrahim Rabadi (2019) investigated whether there was a relationship between vocabulary size and morphological awareness of adult English language learners, and whether their performance differed dependent on word complexity, using the same measures of measuring morphological awareness of students. In order to examine data, this study used two empirical instruments: The Vocabulary Size Test (VST) and the Morphological Awareness Test (MAT). The survey included 90 students from Jordanian universities. The measure of the learners' vocabulary and morphological knowledge had a favorable link. The subjects had a mid-level vocabulary and were not able to generate and use new words utilizing morphemes, according to the findings. Furthermore, there was a favorable correlation between learner's performance on word complexity and learners morphological knowledge.

The findings of this study are different from those of a prior study. (Farsi, 2008) investigated the relationship between morphological awareness and vocabulary knowledge and morphological complexity among EFL University students of Oman. The findings revealed that among University of Oman students, there was no correlation between morphological knowledge, vocabulary quantity, or word complexity. Furthermore, (Novawan et al., 2020) looked at the relationship between morphological awareness and vocabulary knowledge among Saudi EFL students. The findings of this research indicate that the vocabulary size of students is between 4,000 and 5,000 words (4686 word families). Students also performed poorly on the Morphological Awareness Test, according to the findings (i.e. Morphological Structure Test and Morpheme Identification Test). Based on previous research, the researcher saw an opportunity to look into the fifth semester students of the English Department of the Faculty of Teacher Training and Education, Universitas Riau as EFL and to find out whether there is a correlation between morphological awareness and vocabulary mastery. The results showed that there was a relationship between morphological awareness and vocabulary mastery of fifth semester students of English Department FKIP Universitas Riau with a correlation level of "High Correlation".

In this research, the analysis presented the correlation between students' morphological awareness and vocabulary mastery in English Department of FKIP Universitas Riau. 
Nyayu Muharomah Arviyolla ${ }^{1}$,SyofiaDelfi ${ }^{2}$,Dahnilsyah ${ }^{3}$,

J-SHMIC: Journal of English for Academic

Vol 9, No 1, February 2022

Consequently, the results of this study should enable readers to comprehend morphological awareness' correlation with vocabulary mastery. This will allow the readers to apply morphological strategies to learning vocabulary.

\section{CONCLUSIONS}

The purpose of this study is to determine the extent of students' morphological awareness, the extent of students' ability in vocabulary mastery as well as to find out whether there is a correlation between students' morphological awareness and vocabulary mastery. The instrument used to collect the data was Morphological Awareness Test (MAT) with some adaptations from Chang et all (2005) and Vocabulary Level Test that adopted from Webb et all (2017). Thirty-nine students were the participants of the present study. The writer collected the data by the support of Google form due to the online class policy.

The morphological awareness (MA) of students in the $5^{\text {th }}$ semester of English Department is moderate, both in morphological structure and in morpheme identification used in the test were analyzed. It can be concluded that morphological structure was the most successful part in regards to participants answering the question correctly. Students in the English Department performed well on the Vocabulary Level Test when it came to accurately answering questions; the data suggested that students performed better at the 1000 and 2000 levels of the Vocabulary Levels Test than at the higher levels. Then, among the fifth semester English Department students at FKIP Universitas Riau, there is a substantial association between morphological awareness (X) and vocabulary mastery (Y). The coefficient correlation is high, with a value of 0.601 at a significance level of 0.01 . The coefficient correlation exceeds the $r$ table's essential value $(0.601>0.316)$. The result of this research are null hypothesis is rejected, and the research hypothesis which asserts that students who scored well in morphological awareness also scored well in English vocabulary mastery, is accepted. Students can increase their vocabulary understanding more efficiently by using morphological awareness as a strategy of vocabulary learning approach.

\section{REFERENCES}

Adam. (2018). Relationship between Morphological Awareness and Vocabulary Mastery. Anglo-Saxon, 9(1), 24-31.

Anisa, I. (2016). The Vocabulary Mastery of the second Semester Students of Widya Dharma University in academic Year 2015/2016. Magistra, 98, 60-70.

Creswell, J. W. (2012). Planning, Conducting, and Evaluating Quantitative and Qualitative Research.

Delfi, S., \& Yamat, H. (2017). an Analysis of Studies on Teaching and Learning. J-SHMIC : Journal of English for Academic, 4, 101-115. https://journal.uir.ac.id/index.php/jshmic/article/download/703/388

EF Education First. (2020). English Proviency Index. Ef Epi, 1-27.

Emelia Agustianti, Delfi, S., \& Dahnilsyah, D. (2021). The Correlation between University 
Students' Vocabulary Learning Strategies and The Vocabulary Mastery Level. JSHMIC: Journal of English for Academic, 8(2), 153-167. https://doi.org/10.25299/jshmic.2021.vol8(2).7392

Farsi, B. Al. (2008). Morphological awareness and its relationship to vocabulary knowledge and morphological complexity among Omani EFL university students. Unpublished

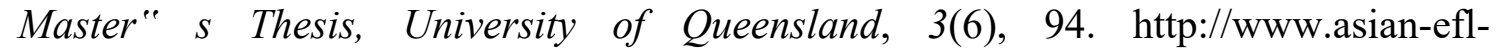
journal.com/Thesis/Thesis-Al-Farsi.pdf?origin=publication_detail

Gay, L. R., Mills, G. E., \& Airasian, P. (2012). EDUCATIONAL RESEARCH.

Hafizh Ana Nafiah. (2017). The Correlation between Students' Morphological Awareness pf Affixes to Their Reading Comprehension. 210093.

Ibrahim Rabadi, R. (2019). Morphological Awareness and Vocabulary Knowledge among English Language Learners. Arab World English Journal, 10(3), 43-63. https://doi.org/10.24093/awej/vol10no3.4

Khairumi, N., Delfi, S., Program, E. S., Training, T., Faculty, E., \& Riau, U. (2020). SecondYear Students of English Study Program. 7, 1-8.

Khairunnisa, N., Delfi, S., \& Supriusman. (2019). 25059-48629-1-SM (7).pdf. J-SHMIC: Journal of English for Academic, 4.

McBride-Chang, C., Wagner, R. K., Muse, A., Chow, B. W. Y., \& Shu, H. (2005). The role of morphological awareness in children's vocabulary acquisition in English. Applied Psycholinguistics, 26(3), 415-435. https://doi.org/10.1017/S014271640505023X

Nation, P. (2001). Teaching Vocabulary. The Modern Language Journal, 53(8), 531-537. https://doi.org/10.1111/j.1540-4781.1969.tb04998.x

Ngoc Yen Dang, \& Webb, S. (2016). Chapter 15: Making an essential word list for beginners. Making and Using Word Lists for Language Learning and Testing, 153-167. https://doi.org/10.1075/z.208.15ch15

Novawan, A., Aisyiyah, S., Miqawati, A. H., Wijayanti, F., \& Indrastana, N. S. (2020). JER| Journal of ELT Research. 5(1), 80-93. https://doi.org/10.22236/JER

Renandya, W. A., Hamied, F. A., \& Nurkamto, J. (2018). The Journal of Asia TEFL English Language Proficiency in Indonesia: Issues and Prospects 1). The Journal of Asia Tefl, 15(3), 618-629. http://dx.doi.org/10.18823/asiatefl.2018.15.3.4.618

Webb, S., Sasao, Y., \& Ballance, O. (2017). The updated Vocabulary Levels Test. ITL International Journal of Applied Linguistics, 168(1), 33-69. https://doi.org/10.1075/itl.168.1.02web 